\title{
Analysis of Factors Affecting BPJS Patients Choosing a Class of Care to VIP Room
}

\author{
Febrian Purwatiningrum \\ Iskak Hospital Tulungagung, \\ Indonesia \\ Email: \\ febrian.ib86@gmail.com
}

Received : March 12, 2019

Accepted : October 13, 2019

Published : November 26, 2019

\begin{abstract}
The increase of assurance participant, impact to increase inpatient at hospital. Some of participant choose to upgrade their treatman class, really if they don't upgrade treatmen class they don't need to pay more for their treatman. Purpose of this research are analysis factors that influence behaviour to upgrade class treatmen to VIP class at dr.Iskak hospital that include of perception, knowledge,income, and family support.This is a kuantitatif reseach with approch cross sectional. The population was all BPJS patient that treat at VIP dr. Iskak hospital Tulung Agung since 1st June until 31 of July 2018. Sample of research were some of BPJS patients that treated at VIP class dr.Iskak hospital Tulungagung $=182$. The data collect by simple ramdom sampling. Independent variables are Perception, Income,Knowledge, Family Support. Dependent variable is Upgrade treatment class to VIP. Statistic analysis with logistic regression. Result of the research, all of independent variable are simultanetaneously influence BPJS patient choosing to upgrade treatmen class to VIP class at dr.Iskak hospital Tulungagung $\mathrm{p}$ value $=0,008$. In partial, perception $\mathrm{p}$ value $0,956(>0,05)$, income p-value $0,001(<0,05)$, knowledge p-value 0,854 ( >0,05), family support p-value 0,021 $(<0,05)$.In this research, income and family support are influencing BPJS patient to upgrade treatmen class. But perception and knowledge are not influencing. And the dominan factor is income. Without good income, behaviour upgrade class treatmen not going to do.
\end{abstract}

Keywords : Perception, Income, Knowledge, Family Support 


\section{INTRODUCTION}

Dalam rangka melaksanakan amanah Undang Undang nomor 36 tahun 2009 tentang kesehatan pemerintah meluncurkan Jaminan Kesehatan Nasional pada awal tahun2014 melalui BPJS sebagai asuransi sosial. Asuransi sosial ini bersifat wajib bagi seluruh rakyat Indonesia sehingga semakin hari jumlah peserta makin bertambah. Bertambahnya peserta BPJS beriringan dengan jumlah pasien yang menjalani rawat inap di rumah sakit yang juga terus mengalami peningkatan,diantara peserta yang rawat inap ada yang melakukan naik kelas perawatan, padahal jika mereka menjalani rawat inap sesuai kelasnya mereka tidak perlu tambah biaya.

Ada beberapa faktor yang mempengaruhi terjadinya perilaku kesehatan,menurut teori Preceeed Proceed, pertama yaitu faktor predisposisi yang meliputi sikap, pengetahuan, persepsi, keyakinan, norma sosial. Kedua faktor pemungkin meliputi pendapatan, kemudahan mencapai fasilitas kesehatan, obat obat yang tersedia, kelengkapan sarana prasarana di fasilitas kesehatan. Ketiga faktor penguat seperti dukungan keluarga, perilaku petugas kesehatan, pengaruh dari tokoh yang dipercaya masyarakat. Pada penelitian ini bertujuan untuk menganalisa faktor yang memepengaruhi terjadinya perilaku naik kelas perawatan oleh pasien BPJS ke VIP di RSUD dr.Iskak Tulungagung yang meliputi faktor persepsi, pendapatan, pengetahuan dan dukungan keluarga.

\section{MATERIALS AND METHODS}

Ini merupakan penelitian kuantitatif dengan pendekatan potong lintang yang dilakukan pada bulan Juni-Juli 2018. Variabel independen penelitian ini adalah persepsi, pengetahuan, pendapatan dan dukungan keluarga. Variabel dependennya ialah naik kelas perawatan ke VIP RSUD dr.Iskak Tulungagung. Jumlah sampel penelitian 182 responden, dengan metode simple random sampling, data dianalisis dengan uji regresi logistik. Instrumen yang dipakai ialah quesioner.

\section{RESULT}

\section{Karakteristik UMUM}

\begin{tabular}{|c|c|c|c|}
\hline No & Karakteristik & & Jumlah Responden \\
\hline \multirow[t]{2}{*}{1} & Jenis Kelamin & Laki-laki & 74 \\
\hline & & Perempuan & 108 \\
\hline \multirow[t]{5}{*}{2} & Umur & $31-40$ th & 22 \\
\hline & & $41-50$ th & 26 \\
\hline & & $20-30$ th & 30 \\
\hline & & $50-55$ th & 33 \\
\hline & & $>55$ th & 71 \\
\hline \multirow[t]{2}{*}{3} & Status pernikahan & Menikah & 158 \\
\hline & & Blm menikah & 24 \\
\hline \multirow[t]{5}{*}{4} & Pendidikan & Tidak sekolah & 2 \\
\hline & & SD & 9 \\
\hline & & SMP & 25 \\
\hline & & SMA & 71 \\
\hline & & $\mathrm{PT}$ & 75 \\
\hline \multirow[t]{5}{*}{5} & Pekerjaan & PNS & 41 \\
\hline & & Karyawan swasta & 42 \\
\hline & & Tidak bekerja & 26 \\
\hline & & Wiraswasta & 39 \\
\hline & & Pensiunan & 34 \\
\hline \multirow[t]{2}{*}{6} & Pendapatan selain gaji & Ada & 29 \\
\hline & & Tidak ada & 153 \\
\hline \multirow[t]{3}{*}{7} & Penanggung jawab rawat inap & Orang tua & 12 \\
\hline & & anak & 46 \\
\hline & & Diri sendiri & 124 \\
\hline \multirow[t]{2}{*}{8} & Kepemilikan asuransi selain BPJS & Ada & 3 \\
\hline & & Tidak & 179 \\
\hline
\end{tabular}




\begin{tabular}{cccc}
\hline 9 & Kelas Kepesertaan BPJS & Kelas 1 & 85 \\
\hline & Kelas 2 & 71 \\
\hline \multirow{2}{*}{10} & $\begin{array}{c}\text { Pernah dirawat di VIP RSUD } \\
\text { dr.Iskak }\end{array}$ & Kelas 3 & 26 \\
\hline & Sudah & 140 \\
\hline & Belum & 42 \\
\hline
\end{tabular}

\section{Karakteristik Data Khusus}

Distribusi responden berdasarkan persepsi didapatkan 163 responden $(89,6 \%)$ mempunyai persepsi yang baik tentang VIP RSUD dr.Iskak Tulungagung. Sedangkan dari tabulasi silang antara persepsi dan kenaikan kelas didapatkan bahwa dari 182 responden hampir setengah responden 102 responden atau 56\% mempunyai persepsi kategori baik dan naik kelas perawatan ke kelas VVIP. Responden sebanyak 47 (25,8\%)mempunyai persepsi baik dan naik kelas perawatan ke VIP. Hasil uji statistik didapatkan hasil $\mathrm{p}$ value 0,418 , yang berarti tidak ada hubungan antara persepsi dengan kenaikan kelas rawat inap di RSUD dr. Iskak Tulungagung .

Dari distribusi frekwensi pendapatan didapatkan hasil terbanyak 136 responden $(74,7 \%)$ memiliki pendapatan diatas UMK Kabupaten Tulungagung tahun 2018. Sedangkan dari tabulasi silang pendapatan dengan naik kelas didapatkan hasil bahwa dari 182 responden sebanyak 83 responden atau 45,6\% mempunyai pendapatan lebih dari UMK memilih naikan kelas rawat inap ke VVIP. Sebanyak 36 responden $(19,8 \%)$ yang memiliki pendapatan >UMK memilih naik kelas ke VIP.Hasil uji statistik didapatkan hasil $\mathrm{p}$ value 0,004 , yang berarti ada hubungan antara pendapatan pasien dengan kenaikan kelas rawat inap pasien di RSUD dr. Iskak Tulungagung dan kekuatan korelasi sedang dengan arah korelasi positif yang berarti semakin tinggi pendapatan pasien, maka semakin tinggi kenaikan kelas rawat inap pasien di RSUD dr. Iskak Tulungagung.

Dari distribusi frekwensi pengetahuan didapatkan hasil terbanyak yaitu 117 responden $(64,3 \%)$ memiliki pengetahuan yang baik,59 responden $(32,4 \%)$ berpengetahuan cukup dan 6 responden $(3,3 \%)$ berpengetahuan kurang.Dari tabulasi silang pengetahuan dan kenaikan kelas perawatan didapatkan hasil 74 responden atau 40,7\% mempunyai pengetahuan kategori baik dan naik kelas perawatan ke kelas VVIP. Sebanyak 35responden $(19,2 \%)$ memiliki pengetahuan bagus dan memilih naik kelas perawatan ke VIP,dan sebanyak 8 responden $(4,4 \%)$ memiliki pengetahuan baik dan memilih naik kelas ke presiden suite. Hasil uji statistik didapatkan hasil $\mathrm{p}$ value 0.583 , yang berarti tidak ada hubungan antara pengetahuan pasien dengan kenaikan kelas rawat inap di RSUD dr. Iskak Tulungagung .

Dari distribusi frekwensi dukungan keluarga didapatkan sebanyak 160 responden atau 87,9\% mempunyai kategori dukungan keluarga yang baik. 22 rsponden $(12,1 \%)$ memiliki dukungan keluarga cukup. Sedangkan dari tabulasi silang didapatkan hasil sebanyak 102 responden atau 56\% mempunyai dukungan keluarga kategori baik dan kenaikan kelas rawat inap di kelas VVIP. Sebanyak 47 responden $(25,8 \%)$ memiliki dukungan keluarga yang baik dan memilih naik kelas ke VIP.Sedangkan 17 responden $(9,3 \%)$ meliki pengetahuan yang baik dan memilih naik kelas ke presiden suite.Hasil uji statistik didapatkan hasil $\mathrm{p}$ value 0.018 , yang berarti ada hubungan antara dukungan keluarga pasien dengan kenaikan kelas rawat inap pasien di RSUD dr. Iskak Tulungagung dan kekuatan korelasi sedang dengan arah korelasi negatif yang berarti semakin baik dukungan keluarga, semakin tinggi kenaikan kelas rawat inap pasien di RSUD dr. Iskak Tulungagung.

\section{Analisis Statistik}

Untuk mengetahui faktor-faktor yang berpengaruh terhadap kenaikan kelas rawat inap pasien di RSUD dr. Iskak Tulungagung dilakukan uji statistik secara multivariat regresi logistik, dengan menggunakan bantuan SPSS for Windows versi 20. Hasil analisisnya adalah sebagai berikut :

Hasil uji Omnibus Test of model coefficient, secara simultan menunjukkan bahwa nilai signifikan $0,008(\leq \alpha 0,05)$, yang berarti dengan tingkat keyakinan $95 \%$, ada minimal satu variabel independen yang berpengaruh terhadap variabel dependen. Sehingga dapat disimpulkan bahwa model dapat digunakan untuk analisis lebih lanjut.

Dari uji statistik Regresi Logistik pengaruh persepsi terhadap kenaikan kelas rawat inap pasien di RSUD dr. Iskak Tulungagung dengan hasil nilai p-value 0,956 lebih dari 0,05, yang berarti tidak ada pengaruh antara persepsi dengan kenaikan kelas rawat inap pasien di RSUD dr. Iskak Tulungagung. 
Dari uji statistik Regresi Logistik pengaruh pendapatan terhadap kenaikan kelas rawat inap pasien di RSUD dr. Iskak Tulungagung dengan hasil nilai p-value 0,001 kurang dari sama dengan 0,05, yang berarti ada pengaruh antara pendapatan dengan kenaikan kelas rawat inap pasien di RSUD dr. Iskak Tulungagung

Dari uji statistik Regresi Logistik mengetahui pengaruh pengetahuan terhadap kenaikan kelas rawat inap pasien di RSUD dr. Iskak Tulungagung didapatkan nilai p-value 0,854 lebih dari 0,05 , yang berarti tidak ada pengaruh antara pengetahuan dengan kenaikan kelas rawat inap pasien di RSUD dr. Iskak Tulungagung

Dari hasil uji statistik Regresi Logistik pengaruh dukungan keluarga terhadap kenaikan kelas rawat inap pasien di RSUD dr. Iskak Tulungagung didapatkan nilai p-value 0,021 kurang dari sama dengan 0,05, yang berarti ada pengaruh antara dukungan keluarga dengan kenaikan kelas rawat inap pasien di RSUD dr. Iskak Tulungagung.

Dari empat variabel yang mempengaruhi kenaikan kelas rawat inap pasien di RSUD dr. Iskak Tulungagung, didapatkan hasil satu variabel yang paling dominan mempengaruhi kenaikan kelas rawat inap pasien, yaitu pendapatan dengan hasil $p$-value $=0,001$ dan Odd ratio $=5,392$, yang berarti jika pasien dengan pendapatan lebih besar dari UMK akan 5 kali berpeluang menaikkan kelas rawat inapnya saat dirawat di RSUD dr. Iskak Tulungagung dibandingkan pasien dengan pendapatan kurang dari UMK.

\section{DISCUSSION \\ Pengaruh Persepsi Terhadap Pasien BPJS Memilih Naik Kelas Perawatan ke Kelas VIP di RSUD dr.Iskak Tulung Agung}

Menurut Gronos, pelayanan adalah suatu rangkaian aktivitas yang bersifat tidak dapat diraba tapi dapat dirasakan yang terjadi akibat adanya interaksi antara konsumen dengan karyawan atau hal lain yang disediakan perusahaan jasa dengan maksud untuk membantu memecahkan masalah pelanggan ( dalam Atik S.W.dan Ratminto,2008).

Menurut Tjiptono (dalam Aditya 2011: 23) bahwa kualitas jasa merupakan sesuatu yang dipersepsikan oleh pelanggan.Pelanggan akan menilai kualitas jasa berdasar apa yang mereka rasakan. Pelanggan akan beralih ke penyedia jasa lain yang lebih mampu memahami kebutuhan pelanggan dan mampu meberikan layanan yang lebih baik.

Kualitas layanan akan membuat pelanggan loyal pada produk dan layanan suatu perusahaan sehingga mempunyai dampak pada peningkatan pasar suatu produk.Kualitas layanan sangat penting untuk mempertahankan pelanggan,perusahaan yang memiliki layanan yang baik akan mendapatkan performa keuangan yang baik (Gilbert dkk,2004)

Kualitas layanan yang rendah akan menimbulkan ketidakpuasan yang berakibat pelanggan kecewa dan menceritakan kepada pelanggan lainnya,sehinggga pelanggan akan beralih ke pesaing lainnya (Lupiyoadi dan Hamdani,2006)

Persepsi pelangaan terhadap kualitas layanan dapat diukur dan dievaluasi melalui dimensi layanan seperti yang dikemukakan oleh Zeithaml,Parasuraman dan Berry yang terkenal dengan SERVQUAL (Service Quality) yang berbunyi "a customer's judgment of overall excellent or superiority of a service", yang diartikan sebagai perbedaan antara kenyataan dan harapan pelanggan dari pelayanan yang mereka terima . Menurut teori ini bahwa dimensi pelayanan terdiri dari lima dimensi yaitu : 1). Tangibles (tampilan fisik) meliputi tampilan gedung,tampilan alat,tampilan karyawan. 2). Reliability (kenyataan) yaitu kemampuan memberikan layanan yang dijanjikan yang dapat diandalkan dan tepat. 3) Responsiveness (daya tanggap) yaitu kesediaan atau kesiapan karyawan memberikan layanan dan membantu konsumen 4). Assurance (jaminan) mencakup pengetahuan,kesopanan dan kemampuan karyawan untuk memperoleh kepercayaan pelanggan 5). Empathy (kepedulian) yaitu kepedulian dan perhatian perusahaan secara individual terhadap konsumen.

Persepsi dalam penelitian ini itu meliputi kenyamanan ruangan, kebersihan ruangan, fasilitas yang disediakan, pelayanan perawat, pelayanan dokter yang merawat, menu makanan serta pelayanan obat yang ada di gedung Graha Hita Husada RSUD dr.Iskak Tulungagung. Hal ini sudah mencakup beberapa hal yang termasuk dalam servqual, sehingga sudah bisa menggambarkan sebagian dimensi kualitas jasa pelayanan di RSUD dr.Iskak Tulungagung.Dari tabulasi silang antara persepsi dan naik kelas perawatan didapatka 163 responden $(89,6 \%)$ memiliki persepsi yang baik, dengan rincian 47 
responden $(25,8 \%)$ yang memilih VIP, 102 responden (56\%) yang memilih ke VVIP, 14 responden yang yang memilih naik kelas presiden suite.

Dari data umum hasil penelitian menunjukkan bahwa sebagian besar responden, yaitu sebanyak 140 responden (76,9\%) adalah pasien lama yang sudah pernah rawat inap di gedung Graha Hita Husada RSUD dr.Iskak Tulungagung. Jadi sebagian besar responden adalah pasien lama (pasien loyal ) yang sudah pernah dirawat di ruang VIP RSUD dr.Iskak Tulungagung dan merasakan kepuasan terhadap pelayanan jasa yang diberikan sehingga mereka memilih ruang VIP kembali. Hal ini sesuai dengan pendapat ahli bahwa kepuasan mempengaruhi loyalitas. Akan tetapi pada penelitian ini persepsi tidak mempengaruhi pemilihan naik kelas perawatan ke VIP, mungkin dikarenakan pada penelitian ini kelima dimensi pelayanan jasa belum tergali sepenuhnya, hanya dimensi tangible saja yang ditanyakan.sedangkan menurut Parasuraman dkk(1990) reliability merupakan dimensi yg terpenting,kemudian disusul assurance lalu tangible, kemudian responsivveness dan terakhir emphathy.

Hasil penelitian ini berbeda dengan penelitian M.Zulfikar,Abdul Ghofar (2010) bahwa faktor psikologi (persepsi) berhubungan dengan keputusan pelanggan dalam memilih jasa pelayanan rawat inap adalah baik (74,3\%).dari uji statistik dengan menggunakan uji korelasi spearman Rho didapatkan nilai 0,001 yang berarti ada hubungan antara faktor psikologi(persepsi) dengan keputusan pelanggan memilih kembali jasa pelayanan.Pelayanan prima yang memuaskan kepada pelanggan rawat inap akan menurunkan kepekaannya terhadap harga, mereka akan rela membayar berapapun asalkan mendapatkan kepuasan sesuai atau lebih dari yang mereka harapkan, sehingga mereka memilih kelas VIP sebagai tempat perawatannya.

Hasil penelitian ini sesuai dengan penelitian Siyoto S. (2015) dalam persepsi dan pemanfaatan fasilitas kesehatan di puskesmas oleh masyakat miskin Kota Kediri, didapatkan hasil bahwa persepsi tentang mutu pelayanan Puskesmas tidak mempengaruhi pemanfaatan pelayanan oleh masyarakat miskin di Kota Kediri, meskipun mayoritas masyarakat miskin menyatakan fasilitas sarana dan prasarana baik.

\section{Pengaruh Pendapatan Terhadap Pasien BPJS Memilih Naik Kelas Perawatan ke Kelas VIP di RSUD dr.Iskak Tulung Agung}

Dari distribusi frekwensi penelitian ini didapatkan bahwa sebagian besar responden yang memilih naik kelas ke VIP sebanyak 136 orang ( $74,7 \%$ ) berpendapatan diatas UMR Kabupaten Tulungagung tahun 2018. Dari hasil tabulasi silang antara pendapatan dengan kenaikan kelas rawat inap didapatkan hasil $\mathrm{p}$ value $=0,004$, yang berarti ada hubungan antara pendapatan pasien dengan kenaikan kelas rawat inap pasien di RSUD dr. Iskak Tulungagung dan kekuatan korelasi sedang dengan arah korelasi positif yang berarti semakin tinggi pendapatan pasien, maka semakin tinggi kenaikan kelas rawat inap pasien di RSUD dr. Iskak Tulungagung.Sedangkan dari analisis regresi logistik, variabel pendapatan mendapatkan hasil $\mathrm{p}$ value $=0,001$, dengan $\alpha<0,005$, hal ini menunjukkan bahwa ada pengaruh yang signifikan antara pendapatan dengan kenaikan kelas ke kelas VIP di RSUD drIskak Tulungagung. Sedangkan nilai odds ratio ( OR) sebesar 5,392, artinya pasien dengan pendapatan diatas UMR berpeluang 5 kali lebih besar untuk melakukan naik kelas ke VIP.

Hasil ini sejalan dengan penelitian Zulfikar M., Ghofar A.(2010) didapatkan hasil statistik uji korelasi sebesar 0,007 , dengan $\alpha=<0,005$ yang berarti ada hubungan antara keputusan memilih kembali rawat inap di RSI Jombang dengan pendapatan, sebagian besar respondennya adalah karyawan swasta.Hasil ini juga sesuai dengan penelitian Hutapea (2009) diketahui bahwa faktor penghasilan (ability) mempunyai pengaruh yang bermakna dalam pemilihan kelas rawat inap, dimana makin tinggi penghasilan makin tinggi kelas rawat inap yang diminati.Dari hasil uji beda ,penghasilan keluarga dengan kelas rawat inap yang dipergunakan ,didapatkan hasil bahwa penghasilan menentukan kelas perawatan yang dipergunakan (contingency coefficient $=0,4287$ dan $p=0,000$ ) .

Hasil penelitian ini juga sesuai dengan penelitian Gaol T (2013 ) tentang analisis pencarian pengobatan dengan sosioekonomi(penghasilan) diperoleh hasil $\mathrm{p}=0,006<0,05$ yang menunjukkan adanya hubungan yang signifikan antara faktor sosioekonomi dengan pencarian pengobatan di Kecamatan medan Kota.Nilai Odd Rasio (OR) sebesar 3,387 pada analisis multivariat artinya bahwa kemungkinan atau peluang masyarakat yang mempunyai sosioekonomi yang baik sebesar 3 sampai 4 kali untuk mencari pengobatan dengan baik dibandingkan masyarakat dengan sosioekonomi kurang

Semakin tinggi pendapatan yang diterima seseorang maka akan menimbulkan kecenderungan untuk memilih dan menggunakan pelayanan kesehatan dengan kualitas dan fasilitas yang lebih baik, 
sedangkan hal itu berlaku sebaliknya jika seseorang mempuyai pendapatan yang kurang maka akan memilih dan menggunakan pelayanan kesehatan yang sesuai dengan apa yang bisa mereka bayar (Lumi, 2014). Menurut Palupi J.K.N. (2016) faktor yang secara statistik signifikan mempengaruhi pilihan naik kelas rawat inap adalah tarif umum rumah sakit $(\mathrm{p}=0,001) ;(2=0,208)$. Hal ini dapat diartikan bahwa pilihan naik kelas rawat cenderung bertambah sebesar 20,8\% setiap ada penurunan tarif umum rumah sakit

Hasil penelitian ini dan beberapa pendapat diatas menunjukkan bahwa pendapatan sangat mempengaruhi tindakan naik kelas perawatan ke VIP oleh pasien BPJS di RSUD dr.Iskak Tulungagung.

\section{Pengaruh Pengetahuan Terhadap Pasien BPJS Memilih Naik Kelas Perawatan ke Kelas VIP di RSUD dr.Iskak Tulung Agung}

Menurut Notoatmodjo (2010), pengetahuan dalam domain kognitif mempunyai enam tingkatan yaitu 1) Tahu (know)diartikan kemampuan mengingat materi yang diterima sebelumya 2) Memahami(comprehension) diartikan kemampuan untuk menjelaskan materi yang diketahui 3) Aplikasi (aplication) diartikan kemampuan untuk menggunakan materiyangtelah dipelajari pada kondisi riil. 4) Analisis (analysis) adalah kemampuan untuk membedakan,memisahkan,mengelompokkan terhadap pengetahuan 5)Sintesis (syntesis) menunjukkkan kemempuan untuk menyusun, merencanakan, meringkss dan sebagainya terhadap suatu teori. Sedangkan faktor yang mempengaruhi pengetahuan seseorang antara pendidikan, pekerjaan, umur, minat, pengalaman,kebudayaan dan informasi ( Mubarak dkk,2007).

Menurut Bruck dalam Manuarang R.M.,Mawardi M.K (2018) disebutkan bahwa pengetahuan suatu produk dibagi dalam 3 kategori yaitu a)Subjective Knowledge/Perceived knowledge yaitu seberapa banyak responden tahu mengenai suatu produk meliputi kategori,merek,ciri suatu produk b) Objective knowledge yaitu seberapa banyak informasi dan jenis informasi yang terdapat dalam memori konsumen c) Experience Based Knowledge mencakup informasi tentang pengoperasian suatu produk dan kapan situasi pembeliannya.

Dalam penelitian ini, berdasarkan tabulasi silang antara pengetahuan dan kenaikan kelas diketahui bahwa dari 182 responden, terdapat 117 dengan pengetahuan baik,dengan rincian 74 responden atau 40,7\% mempunyai persepsi kategori baik dan naik kelas perawatan ke kelas VVIP, 35 responden dengan pengetahuan baik memilih kelas VIP dan 8 responden atau 4,4\% dengan kategori baik memilih presiden suite. Hasil tabulasi silang didapatkan hasil $p$ value 0,854 , yang berarti tidak ada hubungan antara pengetahuan (pemahaman tentang konsep JKN) pasien dengan kenaikan kelas rawat inap di RSUD dr. Iskak Tulungagung .

Sedangkan dari uji regresi logistik didapatkan hasil $p$ value 0,956 yang berarti bahwa faktor pengetahuan (pemahaman tentang konsep JKN) tidak mempengaruhi terhadap BPJS memilih naik kelas perawatan ke kelas VIP di RSUD dr.Iskak Tulungagung.

Berdasarkan hasil distribusi frekwensi diketahui bahwa dari 182 responden, sebagian besar yaitu 117 responden atau 64,3\% mempunyai pengetahuan dengan kategori baik. Pengetahuan dalam penelitian ini ialah pengetahuan pelanggan tentang kelas BPJS dan aturan rawat inap yang ada di BPJS. Hal ini menggambarkan bahwa sebagian besar masyarakat sudah tahu bahwa di sistem BPJS haya dikenal kelas 1,2,3 dan ada konsekwensi tambahan biaya apabila peserta BPJS memilih naik kelas perawatan. Hal ini juga ditunjang oleh rumah sakit dr.Iskak sendiri juga melakukan sosialisasi bahwa peserta BPJS bisa memilih rawat inap di VIP dengan konsekwensi ada tambahan biaya, sosialisasi dilakukan langsung oleh petugas UGD atau poliklinik ,serta adanya pengumuman lewat banner yang banyak terpasang di ruang ruang rumah sakit.

Berdasarkan teori Bruck tersebut pada penelitian ini variabel pengetahuan memang hanya sebatas subjective knowledge/percieved knowledge tentang BPJS tetapi belum sampai mendalam apakah mereka mengetahui bagaimana pemanfaatan BPJS pada saat mereka sakit baik untuk rawat jalan maupun rawat inap. Sehingga pada penelitian ini variabel pengetahuan tidak mempengaruhi perilaku naik kelas perawatan ke VIP.

Sesuai dengan teori Notoatmodjo, dari hasi tabulasi silang variabel pengetahuan bila dihubungkan dengan tingkat pendidikan pada penelitian ini didapatkan bahwa responden dengan pengetahuan yang baik juga memiliki pendidikan yang tinggi yaitu 75 responden (41\%) berpendidikan SLTA dan 71 reponden(39\%) berpendidikan perguruan tinggi. Sesuai dengan penelitian Gaol T.L. 
(2013) yang mendapatkan hasil $p$ value $0,015<0,05$ dan nilai odds rasio 0.769 yang menggambarkan bahwa faktor sosio demografi yang baik (tingkat pendidikan, pengetahuan yang baik tentang kesehatan), maka pada saat menderita sakit mereka akan mencari tempat pengobatan yang baik.

\section{Pengaruh Dukungan Keluarga Terhadap Pasien BPJS Memilih Naik Kelas Perawatan ke Kelas VIP di RSUD dr.Iskak Tulung Agung}

Tugas keluarga dalam bidang kesehatan menurut Friedman dalm Setiadi (2008),ada 5 tugas keluarga dalam bidang kesehatan yang harus diakukan keluarga yaitu : a) Mengenal masalah kesehatan setiap anggota keluarganya. b) Mengambil keputusan untuk melakukan tindakan kesehatanyang tepat bagi keluarga. c) Memberikan perawatan bagi anggota yang sakit atau tidak dapat membantu dirinya sendirikarena cacat atau anggota yang terlalu muda. d) Mempertahankan suasana rumah yang menguntungkan kesehatan dan perkembangan kepribadian anggota keluarga. e) Mempertahankan hubungan timbal balik antara keluarga dan lembaga kesehatan(pemanfaatan lembaga kesehatan yang ada). Dukungan keluarga menurut Friedman dalam Murniasih (2007) adalah sikap, tindakan dan penerimaan keluarga yang bersifat mendukung dan siap memberikan pertolongan dan bantuan jika diperlukan.

Menurut Lawrence Green kesehatan seseorang atau masyarakat dipengaruhi oleh dua faktor yaitu aktor perilaku (behaviour causes) dan faktor diluar perilaku (non behaviour causes). Pada teori ini diuraikan bahwa perilaku itu ditentukan dari tiga faktor yaitu a) Faktor predisposisi (predisposing factors) yaitu pengetahuan, sikap, kepercayaan, keyakinan, nilai-nilai dan sebagainya. b) Faktor pemungkin (enabling factors), yang terwujud dalam lingkungan fisik, tersedianya fasilitas sarana kesehatan, pendapatan c) Faktor pendorong atau penguat (reinforcing factors) yang terwujud dalam sikap,dukungan keluarga

Hasil uji statistik bivariat dan uji kontingensi didapatkan hasil p value 0.018, yang berarti ada hubungan antara dukungan keluarga pasien dengan kenaikan kelas rawat inap pasien di RSUD dr. Iskak Tulungagung dan kekuatan korelasi sedang dengan arah korelasi positif yang berarti semakin baik dukungan keluarga, semakin tinggi kenaikan kelas rawat inap pasien di RSUD dr. Iskak Tulungagung $(\mathrm{r}=0,567)$.

Sedangkan dari hasil uji statistik regresi variabel dukungan keluarga terhadap pemilihan naik kelas perawata ke VIP didapatkan nilai p-value 0,021 $(<0,05)$, yang berarti ada pengaruh antara dukungan keluarga dengan kenaikan kelas rawat inap pasien di RSUD dr. Iskak Tulungagung. Hal ini sesuai teori Lawrence Green bahwa dukungan keluarga yang termasuk dalam faktor penguat sangat mempengaruhi keputusan naik kelas ke VIP untuk perawatan anggota keluarga yang sakit. Serta sesuai dengan teori Friedman bahwa keluarga mempunyai tugas kesehatan bagi anggota keluarganya, diantaranya dalam perilaku mencari perawatan yang tepat.

Dari hasil tabulasi silang dengan dukungan keluarga dengan data pendidikan diperoleh hasil bahwa responden terbesar yaitu 71 responden (39\%) yang mempunyai dukungan keluarga yang baik, memiliki pendidikan lulusan perguruan tinggi tinggi. Dari tabulasi silang dukungan keluarga dengan pekerjaan (tabel 4.25) diketahi bahwa sebagian besar responden memiliki pekerjaan yang baik yaitu 40 responden karyawan swasta,39 responden PNS, 39 sebagai wiraswasta) dan dari data khusus diketahui bahwa sebagian besar responden memiiki pendaptan diatas UMK sebanyak 136 responden. Hal ini sangat berkaitan, keluarga dengan pendidikan yang tinggi dan mempunyai pendapatan yang tinggi maka akan mencari pemanfaatan pelayanan yang makin tinggi.

Sesuai dengan penelitian TA Saifah (2011) dari analisis bivariat didapatkan hubungan yang bermakna dan korelasi yang positif antara dukungan keluarga dan perilaku gizi anak. Hal ini menunjukkan semakin baik dukungan keluarga akan semakin baik perilaku gizi anak

Sejalan juga dengan penelitian Suwardiman D (2011) dimana didapatkan p value $<0,05$ yang berarti bahwa dukungan keluarga yang baik akan menjadikan beban lebih ringan karena ditanggung bersama oleh keluarga.

Hasil penelitian ini juga sama dengan penelitian Sampeluna N,Balqis,Hamzah A (2013) diperoleh hasil nilai $p=0,000(\alpha<0,05)$ yang berarti ada hubungan antara keluarga dengan pemanfaatan pelayanan kesehatan di RSUD Lakipadada Kab. Tana Toraja. Semakin baik dukungan keluarga maka pemanfaatan pelayanan juga semakin tiggi. 
Faktor Dominan yang Mempengaruhi Pasien BPJS Memilih Naik Kelas Perawatan ke Kelas VIP di RSUD dr.Iskak Tulung Agung

Rumah sakit adalah salah satu jenis industri jasa yaitu jasa kesehatan. Namun harus diakui bahwa rumah sakit sebagi industri jasa memiliki ciri khas yang berbeda dengan industri lainnya. Menurut Rachael Massie ada 3 ciri utama yang membedakannya dengan industri jasa lainnya. Pertama : "bahan baku" utama dari jasa kesehatan ini adalah manusia ,sehingga perlu mendapat perhatian dan tanggungjawab pengelola rumah sakit khususnya menyangkut pertimbangan etika dan nilai kehidupan, bukan semata menghasilkan produk dengan proses dan biaya seefisien mungkin. Kedua yang disebut customer (pelanggan) bukan hanya mereka yang menerima pelayanan (pasien), tetapi juga keluarga pasien yang menentukan keputusan di rumah sakit mana pasien akan dirawat. Ketiga pentingnya peran petugas fungsional seperti dokter,perawat,ahli farmasi , ahli gizi,petugas kebersihan agar sejalan dengan misi kerja organisasi.

Dalam melakukan pemasaran dikenal dengan bauran pemasaran (marketing mix).pengertian marketing mix menurut Kotler dan Keller dalm Benyamin Molan (2012:23) yaitu perangkat alat pemasaran yang digunakan perusahaan untuk mengejar tujuan pemasarannya.Sedangkan pengertian marketing mix menurut Buchari Alma (2012:205) yaitu strategi mencampuri kegiatan pemasaran,agar dicari kombinasi maksimal sehingga mendatangkan hasil yang memuaskan.Marketing mix terdiri atas empat komponen yaitu product,price,place,promotion atu dikenal dengan 4P.Dari teori bauran pemasaran salah satunya adalah tarif, pengertian tarif adalah istilah yang digunakan untuk harga sewa suatu barang menurut Tjiptono (2006:151). Sedangkan Sabarguna (2004: 79) berpendapat tarif ialah harga nilai uang yang harus dibayar oleh konsumen untuk mendaptkan atau mengkonsumsi suatu komoditi yaitu barang atau jasa. Peranan tarif dalam pelayanan kesehatan sangat penting untuk menjaga kesinambungan pelayanan,dimana besarnya tarif harus dapat menjamin total pendapatan lebih besar dari total pengeluaran.

Dari data sekunder juga diketahui bahwa tarif kamar di VIP RSUD dr.Iskak Tulungagung sangat terjangkau oleh masyarakat, jika dibandingkan dengan tarif kamar kelas 1,2 reguler selisihnya hanya sedikit. Adapun besarnya tarif adalah tarif kelas 1 sebesar Rp 110.000,00 dan tarif kelas 2 sebesar Rp 80.000,00, sedangkan tarif untuk VIP Rp 150.000,00 dan tarif VVIP sebesar Rp 250.000,00 sedangkan Presiden Suite bertarif Rp 350.000,00. Harga yang sangat terjangkau ini merupakan daya tarik bagi pasien untuk memilih ruang VIP di RSUD dr.Iskak Tulungagung.

Hal ini sejalan dengan penelitian oleh Tak Kee Hui, Ho-Fuk Lou (2011) didapatkan hasil bahwa harga produk yang murah dan pelayanan yang baik adalah hal paling memepengaruhi konsumen. Menurut Palupi JKN (2016) faktor yang secara statistik signifikan mempengaruhi pilihan naik kelas rawat inap adalah tarif umum rumah sakit $(\mathrm{p}=0,001) ;(2=0,208)$. Hal ini dapat diartikan bahwa pilihan naik kelas rawat cenderung bertambah sebesar $20,8 \%$ setiap ada penurunan tarif umum rumah sakit.

Pada penelitian ini, hasil uji regresi menunjukkan bahwa dari empat variabel independen dalam penelitian ini yaitu persepsi, pengetahuan,pendapatan dan dukungan keluarga, yang mempengaruhi variabel dependen kenaikan kelas rawat inap pasien di RSUD dr. Iskak Tulungagung, didapatkan hasil satu variabel yang paling dominan mempengaruhi kenaikan kelas rawat inap pasien, yaitu pendapatan dengan hasil $p$-value $=0,001$ dengan signifikan $\alpha<0.005$ dan Odd ratio $=5,392$, yang berarti jika pasien dengan pendapatan lebih besar dari UMK akan 5 kali berpeluang menaikkan kelas rawat inapnya saat dirawat di RSUD dr. Iskak Tulungagung dibandingkan pasien dengan pendapatan kurang dari UMK.

Hasil penelitian ini didukung oleh Maya Kurniasari (2011), mengatakan faktor ekonomi ikut berperan dalam pemilihan tempat pengobatan. Hal ini dapat dilihat dari klasifikasi pasien yang datang ketempat pengobatan tradisional sebagian besar pekerjaannya adalah buruh kasar, sopir dan tukang parkir.

Sedangkan pada penelitian ini sebagian besar responden yaitu sebanyak 136 responden mempunyai pendapatan diatas UMK, dan dilihat dari jenis pekerjaan responden, sebagian besar responden adalah pegawai sebanyak 83 responden dan wiraswata sebanyak 34 responden yang memiliki pendapatan jauh lebih tinggi dari upah minimum ketenagakerjaan Kabupaten Tulungagung tahun 2018. Sehingga pendapatan pada penelitian ini merupakan faktor yang sangat dominan pada responden untuk melakukan tindakan naik kelas perawatan dengan memilih VIP sebagai tempat perawatannya. Karena meskipun faktor predisposisi dalam penelitian ini adalah pengetahuan baik, persepsi baik, dan faktor penguat dalam penelitian ini adalah dukungan keluarga tetapi bila pendapatan tidak mencukupi, maka perilaku naik kelas juga tidak akan dilakukan 


\section{CONCLUSION}

Ada pengaruh antara dukungan keluarga dengan kenaikan kelas rawat inap pasien ke VIP di RSUD dr. Iskak Tulungagung. Faktor paling dominan mempengaruhi kenaikan kelas rawat inap pasien ke VIP di RSUD dr. Iskak Tulungagung.

\section{REFERENCES}

Gaol, T., L. (2013). Pengaruh Faktor Sosiodemografi, Sosioekonomi dan Kebutuhan Terhadap Perilaku Masyarakat Dalam Pencarian Pengobatan Di Kecamatan Medan Kota, Tesis, M.Kes, Universitas Sumatera Utara, Medan.

Hutapea. (2009). Faktor Yang Mempengaruhi Keinginan (Demand) Masyarakat dalam Pemilihan Rawat Inap di Rumah Sakit, Jurnal Manajemen Pelayanan Kesehatan, Vol. 24, 94-101. Diakses 15 januari 2018, https://juournal.ugm.ac.id/index.php/jmpk/ article/view/2557.

Kemenkes, 2014, Buku Pegangan Sosialisasi Jaminan Kesehatan Nasional, Jakarta, Kemenkes

Menkes, 2014. Permenkes no 28 tentang Pedomam Pelaksanaan Program Jaminan Kesehatan Nasional, Jakarta, Kemenkes

Mubarak, Wahit Iqbal, dkk. 2007. Promosi Kesehatan Sebuah Pengantar Proses. Belajar Mangajar dalam Pendidikan. Yogyakarta: Graha Ilmu.

M. Zulfikar, A.Ghofar,(2010), Faktor Faktor yang Berhubungan dengan Keputusan Pelanggan dalam Memilih Kembali Jasa Pelayanan Rawat Inap di RSI Jombang,Eduhealth 2010

Nara,A. 2014. Hubungan Pengetahuan, Sikap, Akses Pelayanan Kesehatan,Jumlah Sumber Informasi dan Dukungan Keluarga dengan Pemanfaatan Fasilitas Persalinan Yang Memadai oleh Ibu Bersalin di Puskesmas Kawangu kabupaten Sumba Timur,Tesis,Mkes,Universitas Udayana,Bali

Notoatmodjo. 2010, Promosi Kesehatan dan Ilmu Perilaku. Jakarta: Rineka Cipta, 2010.

Palupi,J.K.,Wardani,P., Andarini,S. 2016, Determinan Pilihan Naik Kelas Perawatan Rumah Sakit dari Kelas I ke Kelas VIP, Jurnal Kebijakan Indonesia, 05,176-183

Presiden, 2014, Undang-Undang no 40 tentang Sistem Jaminan Nasional, Jakarta

Sampulena N,Balqis, Hamzah A,2013,Faktor Yang Berhubungan Dengan Pemanfaatan Pelayanan Kesehatan Di RSUD Lakipada Kabupaten Tana Toraja.http://download.portalgaruda.org/article.php?article=148893\&val=2172\&title

Saifah T.A.(2011), Hubungan Peran Keluarga,Guru,Teman Sebaya dan Media Massa dengan Perilaku Gizi Anak Usia Sekolah Dasar di Wilayah Kerja Puskesmas Mabelopura Kota Palu, Tesis, Mkes, Universitas Indonesia

Siyoto,S. dan Muhith, A., 2015, Persepsi dan Pemanfaatan Pelayanan Kesehatan di Puskesmas oleh Masyarakat Penerima jamkesmas, Jurnal Medika majapahit, vol.7,1-90. Diakses 15 jan 2018. http://publikasi. stikesstrada.ac.id/wp-content/uploads/ 2015/ 02/

Suwardiman D. (2011), Hubungan Antara Dukungan Keluarga dengan Bebab Keluarga dalam Mengikuti Regimen Terapeutik pada Keluarga Halusinasi di RSUD Serang ,Tesis,Mkes,Universitas Indonesia 
Tak Kee Hui, , Ho-Fuk Lau, 2011, The Behavior of Hong Kong Cross-Border Shoppers: A Nonparametric Approach, in Joseph S. Chen (ed.) Advances in Hospitality and Leisure (Advances in Hospitality and Leisure, Volume 7) Emerald Group Publishing Limited, pp.89 10 